- Projects may be single purpose or comparative in scope; they may be investigative or operational in focus. Professional work attachments should involve some consideration of relevant issues of a larger magnitude than basic employment abroad. Proposals that have a pragmatic bearing on issues of common concern to librarians in the U.S. and U.K. are particularly welcome.

- Awards are for a minimum duration of three months and grantees are expected to be paid leave of absence from their home institution. The grantee will receive a fixed grant of approximately 2,500 British pounds, paid in pounds sterling, to cover travel and other expenses. 1989.

- Deadline for applications is September 15,

For more information and a list of libraries approved for affiliation, please call or write Steven Blodgett or Michael Doyle of the Council for International Exchange of Scholars, 3400 International Drive, N.W., Suite M-500, Washington, DC 20008-3097; (202) 686-6239.

\title{
ACRL programs in Dallas
}

\section{This year's conference programs feature invisible users, designer genes, and infostructure.}

\section{Anthropology and Sociology Section}

“Access to Anthropological Field Notes: Preservation, Collection and Ethical Issues" (Sunday, June 25, 9:30 a.m.-12:30 p.m.) will feature a panel of four speakers: Anthony Seeger, curator of the Folkways Collection, Smithsonian Institution; Mary Elizabeth Ruwell, archivist, Northeast Document Conservation Center; Kathleen T. Baxter, reference archivist for the National Anthropological Archives, Smithsonian Institution; and Mark Handler, librarian, Stanford Law Library.

\section{Art Section}

"Networks for Cooperation in the Arts" (Sunday, June 25, 2:00-5:00 p.m.) will explore the state-of-the-art of cooperative ventures among libraries serving the arts. The origin, purpose, membership, scope, governance, accomplishments, and facilities of several major cooperatives representing different disciplines will be featured: "Getting Our Act Together: The Performing Arts Libraries Network of Greater Los Angeles," Joan D. Kunselman, UCLA; "Concerning A\# Music Cooperative (Boston Area Music Libraries),"William F. Coscorelli, University of Georgia; "A Portrait of Collaboration and Confluence in the Fine Arts
(Washington Art Library Resources Committee)," Margaret Culbertson, University of Houston; and "New Bindings for Old Libraries: The Philadelphia Area Consortium of Special Collections Libraries," Kathleen Reed, Drexel University.

\section{Bibliographic Instruction Section}

"Invisible Users/Visible Technology: BI Beyond the Library" (Sunday, June 25, 2:00-5:30 p.m.), will explore the current and future instructional needs of invisible users of online catalogs and other databases, and the challenges, choices and opportunities BI librarians will face in meeting those needs. The program will open with the presentation of the Miriam Dudley BI Librarian of the Year Award. Speakers will include Sally Kalin, Pennsylvania State University; Betsy Baker, Northwestern University; and William Mischo, University of Illinois at Urbana-Champaign. Following the program there will be an orientation to the Bibliographic Instruction Section for new and prospective members.

\section{Black Studies Librarianship Discussion Group}

“Authors/Publishers: Barriers to Access” (Satur- 
day, June 24, 2:00-4:00 p.m.) will focus on African-American out-of-print books, publishing problems, and limited marketing. Authors Margaret Walker, Radrersad Arnold, and Octavia Butler will be the featured speakers.

\section{College Libraries Section}

"Campus Relations: The Challenge of Conflicting Expectations" (Sunday, June 25, 9:30 a.m.-12:00 noon), cosponsored by the Community and Junior College Libraries Section, will stimulate thought on mutual expectations of various academic groups, conflict resolution, and the integration of the library into the intellectual life of the campus. Speakers will be John E. Paynter, provost and dean, University of Dallas; Robert V. Blystone, professor of biology, Trinity University; Mignon Adams, library director, Philadelphia College of Pharmacy and Science; and Evan Farber, director of Earlham College Library.

\section{Community and Junior College Libraries Section}

"Responding to the Needs of Developmental Students" (Saturday, June 24, 9:30 a.m.-12:30 p.m.) includes an overview, a panel presentation and a summary of information on developmental students. Specific topics include law and legislation, library use instruction, and the students' future in learning resources centers. Scheduled speakers are Julie Beth Todaro (Austin Community College), Dorothy Martinez (Austin Community College), Eileen Dubin (Case Western Reserve University), and Barbara Murray (Pensacola Junior College).

The section is sponsoring a tour of the Collin County Community College District Learning Resources Center, at the Spring Creek Campus in Plano, Texas, Monday, June 26. Tour buses will depart at 8:00 a.m. from the Convention Center and will return at 1:00 p.m. to the site of the ACRL President's Program. Advance registration is required by June 2. Make $\$ 8.00$ checks payable to Paul Dumont and send to: Paul Dumont, Dallas County Community College District, $4343 \mathrm{~N}$. Highway 76, Mesquite, TX 75150. Lunch is not included in the fee but will be available at the college cafeteria.

CJCLS will also host a dinner at the City Club on the 69th floor of the NCNB Tower, 3200 One Main Place, Friday, June 23, 6:30-10:00 p.m. Larry Tyree, chancellor of the Dallas Community College District, will speak on "Serving Special Needs." Other entertainment will be provided.

\section{Education and Behavioral Sciences Section}

"Selecting, Evaluating and Creating Policies for Computer-Based Resources in the Behavioral Sciences and Education" (Monday, June 26, 9:30 a.m.-12:30 p.m.), cosponsored by the RASD
Machine-Assisted Reference Section, will review the evaluation of computer-based resources to match institutional needs; the selection of computer resources (software, machine-readable data files, data tapes, compact disks); and the development of policies related to computer-based resources, including licensing, security, contractual agreements and use policies. The speakers will be Peggy Seiden, Carnegie-Mellon University; Katherine Chiang, Cornell University; and Kathy M. Jackson, Texas A\&M University. Audience participation in a question and answer session is encouraged. The EBSS business meeting will follow the program.

The EBSS Psychology/Psychiatry Committee will present "Collection Coordination for Psychology/Psychiatry" (Monday, June 26, 2:00-4:00 p.m.), featuring speakers Marsha S. Clark (New York University), Susan Gangl (University of Minnesota), JoAnn Mulvihill (Arizona State University), Judith Segal (Hunter College School of Social Work), and David E. Shontz (University of Florida).

\section{English and American Literature Discussion Group}

"The Nature of Literary Scholarship" (Sunday, June 25, 2:00-5:30 p.m.) will address how literary scholarship has changed in recent years and how those changes have affected collection development within academic libraries. Speakers will include Harrison T. Meserole, Texas A\&M University; Marianne Gaunt, Rutgers University; Eric Carpenter, Oberlin College; and Richard Heinzkill, University of Oregon.

\section{Law and Political Science Section}

"The Numbers Game: Public Opinion Data and Libraries" (Sunday, June 25, 2:00-4:00 p.m.) consists of a panel of three speakers who will address the history and scope of public opinion polling and research, provide an inside look at data collection techniques, and offer a librarian's perspective on providing effective access to this data. Panelists include James Benniger, Annenberg School of Communications, University of Southern California; John Weekley, president of Weekley/Gray/McKinney, Inc., Dallas; and Jim Jacobs, University of California at San Diego Library.

\section{Rare Books and Manuscripts Section}

"Collecting Local History and Promoting Its Use" (Sunday, June 25, 2:00-5:30 p.m.), cosponsored by the SAA/ALA Joint Committee on Library/Archives Relationships.

A reception for the winners of the Exhibition Catalogues Awards will be given after the program from 5:30-6:30 p.m. 


\section{Science and Technology Section}

"Designer Genes: A Crash Course in Biotechnology Issues and Resources" (Tuesday, June 27, 9:30 a.m. $-12: 30$ p.m.) will feature an overview of current technology, a description of ethical issues, a review of recombinant DNA techniques, and a discussion of issues in animal research at universities. Speakers include: Maude Hinchee, Monsanto Corp. (plant genetic engineering); Bernie Rollin, Colorado State University (animal genetic engineering); Tom Darby, University of Texas Animal Research Center (animal welfare in a research facility); and George McGregor, Cetus Corp. (the role of the information professional).

\section{Slavic and East European Section}

"The Marketplace: Recruitment of Area Specialists" (Sunday, June 25, 2:00-4:00 p.m.) is the outgrowth of a growing concern for the lack of trained area specialists, a lack that is felt in reference, cataloging, bibliography, and in all area programs. $\mathrm{Al}$ though the focus of the program is Slavic studies, other area program needs will also be treated. Harold Leich, Library of Congress, will give a history of Slavic librarianship in the United States. Robert Karlowich, Pratt Institute, will discuss the necessary educational background for Slavic and area program librarianship. A third speaker will offer the point of view of a library administer or library school dean. Panelists will comment on the presentations from their own points of view.

\section{University Libraries Section}

"InfoStructure: Building the New Campus Information Infrastructure" (Saturday, June 24, 2:00-4:00 p.m.), cosponsored by the Library and Information Technology Association, will address the new information infrastructure that is based on computer technology, specialized software, telecommunication networks, and digitized databases. The challenge is for universities and their libraries to work together to provide access to the data needed by their communities and to implement technology so as to remove barriers to needed information. William Y. Arms (vice-president for academic services at Carnegie-Mellon University) and Thomas J. Michalak (director of university libraries at Carnegie-Mellon) will discuss the "vision" of this new infrastructure, the process used to identify objectives, and the basis for their approach to this challenge. Susan J. Logan (coordinator of library automation at Ohio State University) and Kimberly Douglas (head of reader services at the California Institute of Technology) will review the approaches their universities are taking to meet the same challenge.

\section{Western European Specialists Section}

"Austria, Switzerland, and the Two Germanies: Collection Building and Bibliographic Control"
(Monday, June 26, 9:30 a.m.-12:30 p.m.), cosponsored by the RASD Collection Development and Evaluation Section and the RTSD Resources Section, will deal with the building of North American German-language collections and with the intellectual access to them. Agnes Peterson of the Hoover Institution will describe the beginnings and growth of a highly focused collection on mod ern Central European history and politics. Richard Hacken, Brigham Young University Library, will trace the development of a more general corpus of German materials-the German-language social science and humanities collections at a mediumsized research library. Louis Pitschmann, University of Wisconsin-Madison Libraries, will discuss why certain German materials are not widely collected by North American libraries. Finally, Gail Hueting, University of Illinois at UrbanaChampaign, will examine the present and future of U.S.-German cooperation in bibliographic control.

\section{Women's Studies Section}

"Funding Strategies for Women's Studies Collections: Resources, Politics and Management" (Sunday, June 25, 9:30 a.m.-12:30 p.m.), cosponsored by the ALA Committee on the Status of Women in Librarianship, will address the contro-

\section{Other programs}

LAMA Buildings and Equipment Section, Equipment Committee. Preconference on Lighting (Friday, June 23) will feature guest speakers representing architects, librarians, and lighting designers and engineers.

LAMA Library Organization and Management Section, Research in Organization and Management Issues Discussion Group. "Motivation in Libraries: Applying Herzberg" (Monday, June 26, 2:00-4:00 p.m.) will use the suggestions in Frederick Herzberg's article, "One More Time: How Do You Motivate Employees?" to see if they are applicable to the library environment.

LAMA Personnel Administration Section, Supervisory Skills Committee. "Dear Personnel Officer: Solutions to Your Most Pressing Personnel Problems" (Sunday, June 25, 2:00-4:00 p.m.) will address the concerns of supervisors on all levels. Questions for the panel may be pre-submitted in writing to: Abby Kratz, University of Texas at Dallas, $2601 \mathrm{~N}$. Floyd Road, Box 643, Richardson, TX 75083-0643.

LITA Technical Standards for Library Automation. "The Lay of the LAN" (Saturday, June $24,9: 00$ a.m.-12:00 noon) will review local area network technology, identify and compare alternatives, and help sort out choices. Speakers include Robert Walton, Gail Persky, Charles Brown, and Russell Buchanan. 
versy over how women's studies should be supported financially in the library. Beth Stafford (University of Illinois at Urbana-Champaign) will present a state-of-the-art report on her recent survey of women's studies programs; Dora Biblarz (Arizona State University) will discuss how to manage internal library funds; Margie Shurgot (Aura- ria Library) will offer insights about external fundraising; and Hilda Smith (University of Cincinnati) will describe the establishment of a Friends of Women's Studies endowment at her institution. Small group discussions will follow the presentations.

\section{HBCU's prepare for accreditation}

A preconference for Historically Black Colleges and Universities and others undergoing accreditation by the Southern Association of Colleges and Schools (SACS) will be held June 23-24, 1989, at the Dallas Convention Center, Dallas, Texas.

Sponsored by the ACRL Historically Black College and University Project Planning Committee, the program will assist librarians going through the accreditation process, especially in the region served by SACS. It will aid them in preparing for accreditation, becoming familiar with the SACS "Criteria" document, and increasing their clout with administrators and with the Self-Study Committee. Aimed at library directors and those in charge of the library portion of the self-study, it will target historically black institutions but not be limited to them.

\section{What you'll learn} tion;

-SACS' principles and philosophy of accredita-

-How to apply the "Criteria" for the Library, as described in Section 5.2 of the document;

-What the library must do and what it should do to meet the SACS criteria;

-What the SACS requirements are for Services, Collections, Staff, and Institutional Relationships.

\section{Speakers}

- Jack Allen, executive director of the Southern Association of Colleges and Schools, on institutional effectiveness and the role of the library.

- Beverly P. Lynch, dean of the Graduate School of Library and Information Science at the

\section{YES! I want to prepare for accreditation}

Name (as it should appear on the badge):

City

State Zip

Telephone

Payment information

\begin{tabular}{lr} 
ACRL members & $\$ 25$ \\
Non-members & $\$ 30$ \\
Late registration fee & $\$ 5$ \\
Amount paid: & \\
\hline
\end{tabular}


University of California, Los Angeles, on the purpose of accreditation.

\section{Facilitators}

- Jessie Carney Smith, head librarian, Fisk University Library and Media Center.

- Barbara Williams Jenkins, dean of library and information services, South Carolina State College.

- Casper L. Jordan, deputy director, AtlantaFulton County Public Library.

- Nicholas E. Gaymon, director of libraries, Florida A\&M University.

- Lorene B. Brown, director, Atlanta University School of Library and Information Studies.

- Carole R. Taylor, director, Fort Valley State College Library.

\section{How to register}

Register by mail by completing the registration form on page 412 and returning it to: HBCU Preconference, ACRL/ALA, 50 East Huron St., Chicago, IL 60611-2795.

Registration includes coffee breaks and social hour. Attendance will be limited to the first $60 \mathrm{reg}$ istrants. Registration deadline is June 1, 1989.

\section{Payment information}

ACRL members $\$ 25$ (please give your member- ship number), non-members $\$ 30$, late registration fee $\$ 5$. If you're charging, please include your credit card number.

ACRL is partially subsidizing the preconference as part of its commitment to its Strategic Plan, Goal II, Subgoal E, "To strengthen libraries in institutions serving minorities."

\section{President's Program}

"A Look into the Future: Public Services for a Changing Higher Education" (Monday, June 26, 2:00-5:00 p.m.) will review the changes higher education will undergo between now and the turn of the century. A major figure in American higher education will be the keynote speaker. The findings of an ACRL Think Tank of nationally recognized leaders in academic librarianship, held in April, will be presented and the audience will then be asked to vote on each of the major findings of the Think Tank. Results of the vote will be announced at the program's close, thanks to the optical mark readers provided by National Computer Systems.

A reception in honor of the ACRL Academic or Research Librarian of the Year, John McGowan, will be held from 5:00-6:00 p.m., sponsored by the Baker and Taylor Company.

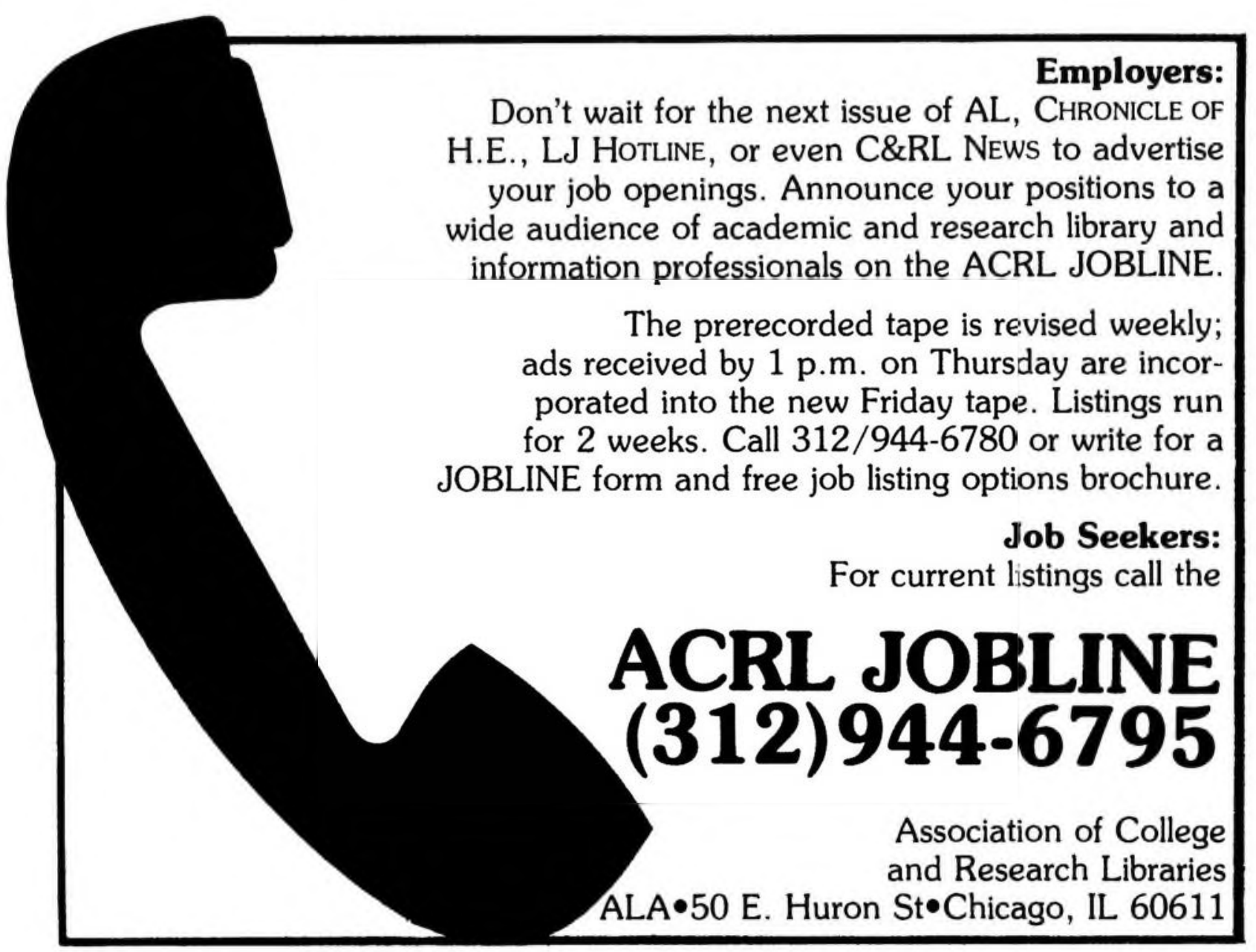

May 1989 / 413 


\section{ACQUISITION PERSPECTIVES}

5. Monographs in continuation and standing orders are given special attention. Your first volume required and all future volumes will be delivered as soon as they become available.

Write or call for details about our reliable standing order service to $\mathrm{l}$ braries.

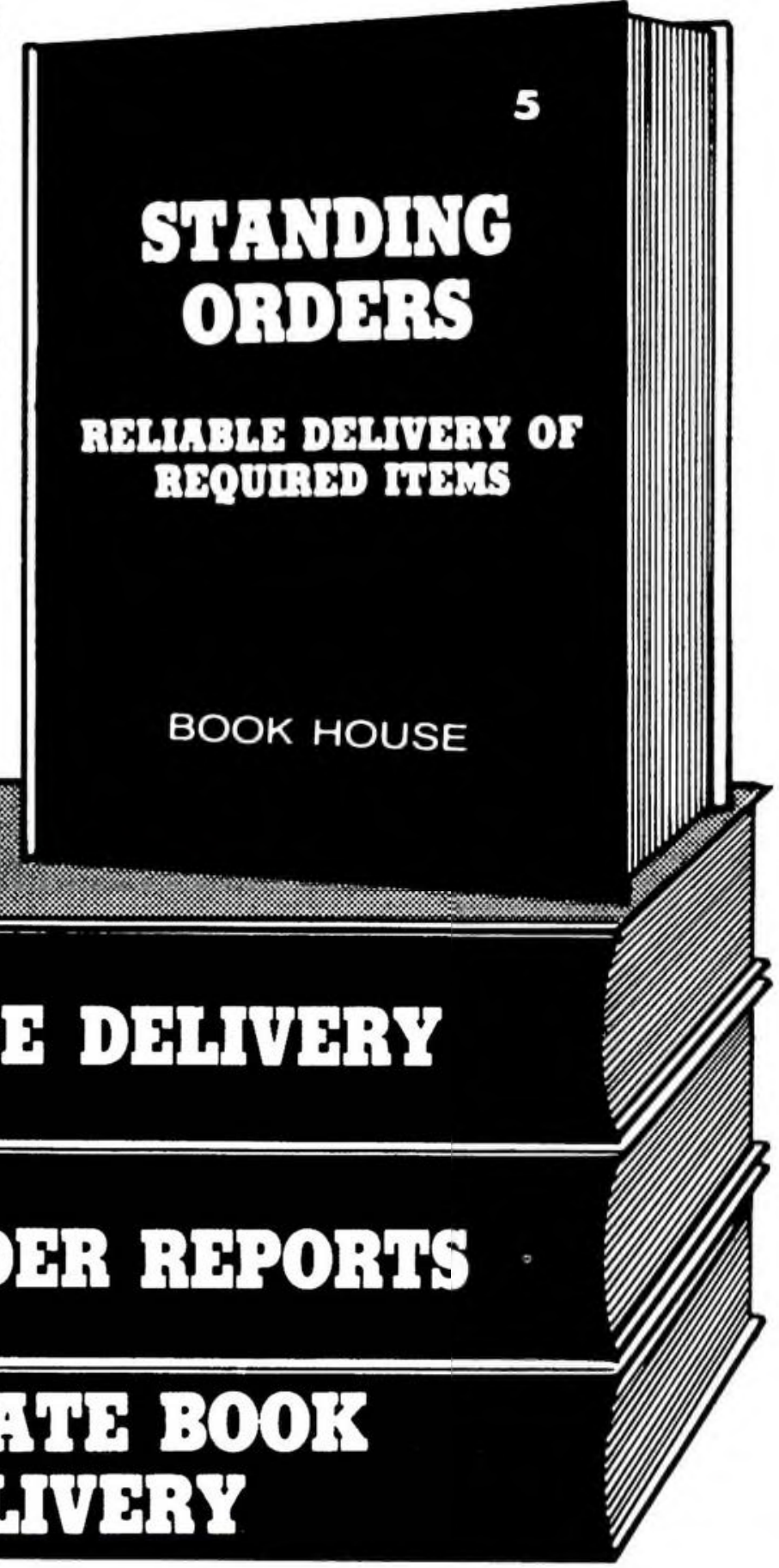

\section{CALL TOLL-FREE TODAY \\ 1-800-248-1146}

In Canada \& Michigan

CALL COLLECT (517) 849-2117

OCLC Vendor No. 17397

SAN $169-3859$

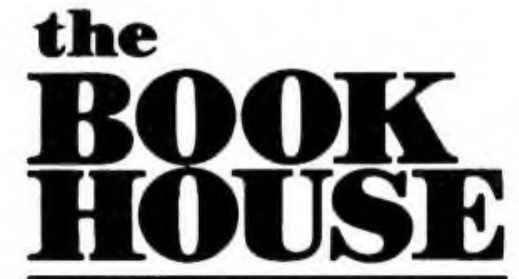

JOBBERS SERVING LIBRARIES WITH ANY BOOK IN PRINT SINCE 1962 208 WEST CHICAGO STREET JONESVILLE, MICHIGAN 49250 


\section{Cancellation Policy}

Written notice of cancellation received by June 2,1989 , will be honored subject to a $\$ 15$ cancellation charge. No refunds for cancellation after June 2 . The Preconference may be canceled if there is insufficient registration. If it is canceled, ACRL cannot be responsible for cancellation or change charges assessed by airlines or travel agencies.

None of the registration fee is for meal or entertainment expenses. You should consult your tax adviser regarding the deductibility for federal income tax purposes of various components of the registration fee.

\section{ACRL meetings in Dallas}

\section{A tentative schedule for ALA's Dallas Conference, June 24-29, 1989.}

\section{ACRL BOARD OF DIRECTORS}

Orientation breakfast: Saturday, June 24, 8:00-9:00 a.m.

First meeting: Saturday, June 24, 2:00-4:00 p.m.

Second meeting: Tuesday, June 27, 2:00-5:30 p.m.

\section{ACRL GENERAL}

Orientation for new chairs: Friday, June 23, 4:30-5:30 p.m.

President's Program/Membership: Monday, June 26, 2:00-5:00 p.m.; reception, 5:00-6:00 p.m.

\section{ACRL DIVISIONAL C OMMITTEES}

Academic Library Statistics: Saturday, June 24, 8:00-9:00 a.m.; Monday, June 26, 8:00-9:00 a.m.

Academic Status: Sunday, June 25, 9:00-11:00 a.m.; Monday, June 26, 9:00-11:00 a.m.; Tuesday, June 27, 9:00-11:00 a.m.

Appointments and Nominations: Saturday, June 24, 9:00-11:00 a.m.; Monday, June 26, 2:00-6:00 p.m.*

Audiovisual: Sunday, June 25, 9:00-11:00 a.m.; Monday, June 26, 9:00-11:00 a.m.

ACRL/AECT Joint Committee on Two-Year Colleges: Friday, June 23, 2:00-5:30 p.m.; Monday, June 26, 4:00-5:30 p.m.
Budget and Finance: Saturday, June 24, 9:30 a.m.-12:30 p.m.; Sunday, June 25, 9:30 a.m.-12:30 p.m., 2:00-5:30 p.m.; Tuesday, June 27, 8:00 a.m.-12:30 p.m.

Constitution and Bylaws: Saturday, June 24, 8:00-11:00 a.m.; Monday, June 26, 8:00-11:00 a.m.

Copyright: Saturday, June 24, 8:30-11:00 a.m.; Sunday, June 25, 9:30-11:00 a.m.

Extended Campus Library Services Guidelines: Sunday, June 25, 8:00-10:00 p.m.; Tuesday, June 27, 9:00-11:00 a.m.

Faculty Advisory Committee Orientation Material Task Force: Sunday, June 25, 9:00-11:00 a.m.

Financial Development Task Force: Monday, June 26, 9:30 a.m.-12:00 noon.

International Relations Task Force: Saturday, June 24, 9:00-11:00 a.m.; Sunday, June 25, 9:00-11:00 a.m.

Library Access Task Force: Sunday, June 25, 8:00-10:00 p.m.

\section{Correction}

The Hugh Atkinson Memorial Award will be presented to Thomas Michalak at a reception in his honor on Sunday, June 25, 4:30-6:00 p.m., during the ALA Annual Conference in Dallas. 